\title{
Antibacterial Activities of Some Schiff Bases Involving Thiosemicarbazide and Ketones
}

\author{
S. M. S. Shariar ${ }^{1, *}$, M. Jesmin ${ }^{2}$, M. M. Ali ${ }^{2}$ \\ ${ }^{1}$ Department of Applied Chemistry and Chemical Technology, Faculty of Food Science and \\ Technology, Chittagong Veterinary and Animal Sciences University, Chittagong - 4202, Bangladesh \\ ${ }^{2}$ Department of Applied Chemistry and Chemical Engineering, Rajshahi University, \\ Rajshahi - 6205, Bangladesh \\ *E-mail address: shahan.acrubd@gmail.com
}

\begin{abstract}
Three Schiff bases derived from thiosemicarbazide and ketones (Vanillin, Benzophenone and Acetophenone) were used to study their antibacterial activities against some pathogenic bacteria by disc diffusion method. Of these, benzophenone thiosemicarbazone showed significant antibacterial activity as compared with that of Kanamycin. All these three compounds were found to possess cytotoxic effect. Minimum inhibitory concentration of these compounds was also determined.
\end{abstract}

Keywords: Antibacterial activity; Minimum inhibitory concentration; Brine shrimp lethality

\section{INTRODUCTION}

Schiff bases are the important class of compounds owing to their wide range of biological activities and industrial applications. These compounds are now used to formulate anticancer $^{1}$, anti $\mathrm{HIV}^{2}$, antitubercular ${ }^{3}$, antiviral ${ }^{4}$, antimalarial ${ }^{5}$ drugs. Many potent antibacterial and antifungal agents have also been prepared. Search of novel antibacterial medicines are very much needed in present time especially for tropical countries like Bangladesh. A large number of antibacterial agents are available to manage pathogenic microorganisms in nature. These treatments however could not completely destroy such organisms, probably due to the widespread irrational, unscientific and apathetic use of such agents. The survived microorganisms have matched the ingenuity in developing their own defenses. As a result such drugs gradually lose their effectiveness in action. Repetition and overdose of such drugs often cause severe environmental pollution. In order to get rid of this situation, it has become a common practice to find out safer, more effective and inexpensive new chemical compounds as antibacterial agents. In this context a series of researches with various compounds have been carried out by different workers ${ }^{6-10}$. In the present paper, the antibacterial activities of three Schiff bases namely vanillin thiosemicarbazone (VTS), benzophenone thiosemicarbazone (BTS) and acetophenone thiosemicarbazone (ATS) have been studied. In addition the cytotoxic effects and minimum inhibitory concentrations (MIC) have also been evaluated. 


\section{EXPERIMENTAL}

\section{1. Chemicals}

All the chemicals used throughout the research work were purchased from BDH (England) and used without further purification. Solvents were distilled prior to use. All the reagents used were of commercial grade.

\section{2. General procedure for the synthesis of the compounds}

The compounds were synthesized by the method in the same way as described in literature ${ }^{11,12}$. Alcoholic solutions of thiosemicarbazide and ketones (Vanillin, Benzophenone and Acetophenone) were mixed in 1:1 molar ratio. The mixture was refluxed for 2-3 hours when crystalline product was obtained. The crystals were separated out from the mother liquor, recrystallized several times from alcoholic solution, dried in an oven at $50{ }^{\circ} \mathrm{C}$ and finally stored in a desiccator.

\section{3. Characterization of the synthesized compounds}

The synthesized compounds were characterized by taking, physical analysis data, melting points ${ }^{11-13}$, and conducting infrared spectral (IR) studies (as KBr disc by a Shimadzu FTIR, Japan).

\section{4. Antibacterial screening}

Antibacterial activities of the compounds were measured by observing the growth response of various microorganisms. The susceptibilities of such growth rate of microorganisms were measured in vitro by disc diffusion method ${ }^{15}$.

A loop full of the given test strain was inoculated in $30 \mathrm{~mL}$ of nutrients broth and incubated for 24 hours in an incubator at $30^{\circ} \mathrm{C}$ in order to activate the bacterial strain activity. $20 \mathrm{~mL}$ of the nutrients agar media was added in to $120 \mathrm{~mm}$ diameter petridishes. $0.1 \mathrm{~mL}$ of the activated strain was inoculated into the media when it reached the temperature of $37{ }^{\circ} \mathrm{C}$. The media was allowed to solidify. After solidification of the media, a sterilized (BBL, Cocksrvile, U.S.A) filter paper disc (3 mm diameter) for sample and standard drug kanamycin $(30 \mu \mathrm{g} / \mathrm{disc})$ disc were taken in the petridishes. The test samples were applied on the disc with the help of a micropipette in an aseptic condition, controls were run (for each bacterial strain and each solvent), where pure solvent was applied on the disc in the petridishes. The petridishes were incubated for 24 hours at $37{ }^{\circ} \mathrm{C}$. The inhibition zone formed by three compounds against the particular test bacterial strain determined the antibacterial activity. The diameter of zones showing complete inhibition $(\mathrm{mm})$ was measured and the growth inhibition was calculated with reference to positive control.

\section{4. 1. Preparation of stock solution of test samples for antibacterial screening}

Exactly $3 \mathrm{mg}, 10 \mathrm{mg}$ and $20 \mathrm{mg}$ of BTS and ATS were dissolved separately in $1 \mathrm{ml}$ of DMSO to get concentration of 30,100 and $200 \mu \mathrm{g} /$ disc respectively. Similarly $10 \mathrm{mg}, 20 \mathrm{mg}$ and $30 \mathrm{mg}$ of VTS were dissolved separately in $1 \mathrm{~mL}$ of DMSO to get concentration of 100 , 200 and $300 \mu \mathrm{g} /$ disc respectively. 


\section{5. Minimum inhibitory concentration (MIC)}

The MIC of the test compounds were determined by serial tube dilution technique ${ }^{16}$ against the same bacteria as used for antibacterial screening. Nutrient agar media was used for this purpose. Decreasing concentrations of test compounds were prepared in serial two fold dilution using the stock solution. Bacterial suspension $(10 \mu \mathrm{L})$ containing $10^{7}$ cells $/ \mathrm{mL}$ was inoculated into all tubes. After incubation for 24 hours at $37^{\circ} \mathrm{C}$, the test tube with no visible growth of the microorganism was taken to represent the MIC value of sample in $\mu \mathrm{g} / \mathrm{mL}$.

\section{6. Brine shrimp lethality bioassay}

The cytotoxic effect of the test compounds was studied by the method as described by Attaur Rahman et al ${ }^{17}$. Brine shrimp (Artemia salina) eggs were hatched in artificial sea water (prepared by dissolving $38 \mathrm{~g} \mathrm{NaCl}$ in one liter distilled water) at room temperature under constant aeration for 48 hours. Stock solutions of the Schiff bases $(10 \mathrm{mg} / \mathrm{mL})$ in DMSO) were added to each vial, so that final concentration of the compounds became $0,10,20,40$, 60,80 and $100 \mu \mathrm{g} / \mathrm{mL}$ after diluting them to $5 \mathrm{~mL}$ with sea water. To each vials, 10 living shrimps were added and allowed to stay there for 24 hours. The survived nauplii in each vial were counted and the results were noted.

\section{RESULT AND DISCUSSION}

\section{1. Synthesis}

Schiff bases were prepared by refluxing of thiosemicarbazide and ketones (Vanillin, Benzophenone and Acetophenone) in ethanol in good yield. The reactions of synthesis are shown in Figure 1.

\section{Compound: VTS}<smiles>CNC(=S)NN</smiles><smiles>COc1cc(/C=N/NC(N)=S)ccc1O</smiles>

Vanillin thiosemicarbazone

Compound: BTS 


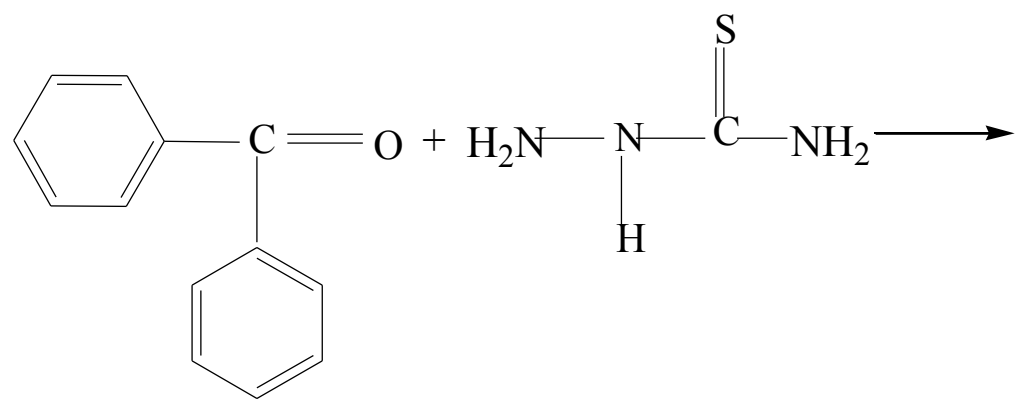

Benzophenone Thiosemicarbazide

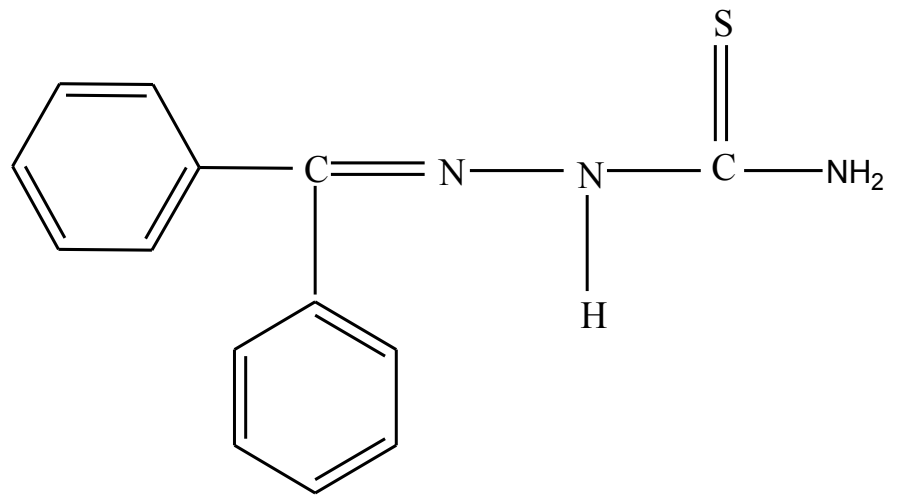

Benzophenone thiosemicarbazone

\section{Compound: ATS}

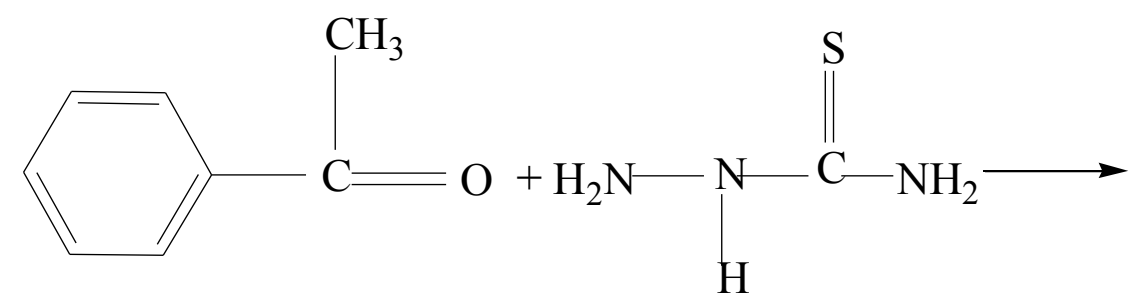

Acetophenone

Thiosemicarbazone 


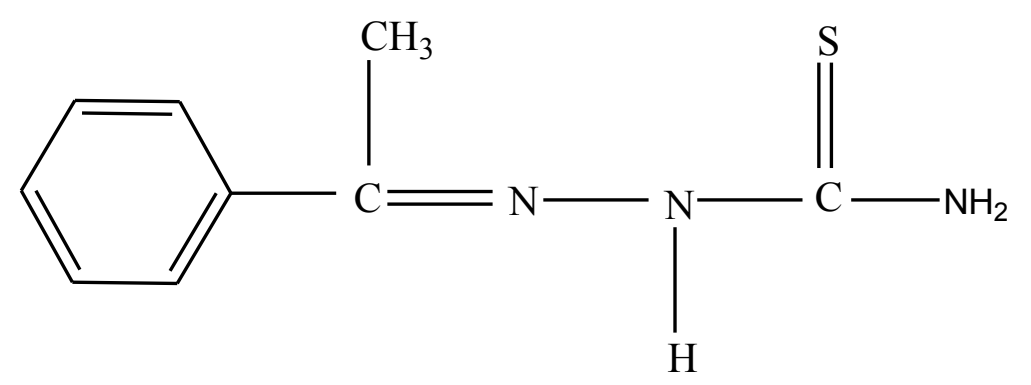

Acetophenone Thiosemicarbazide

Figure 1. Structure of the three Schiff bases derived from thiosemicarbazide and ketones.

The synthesized compounds were verified by taking melting points and conducting infrared spectral (IR) studies which are given in Table 1 . The new bond $>\mathrm{C}=\mathrm{N}-$ (azomethine) formed during the synthesis in all the cases was confirmed from IR spectrum of $>\mathrm{C}=\mathrm{N}-$ bond at around $1630 \mathrm{~cm}^{-1}$ which was in this accordance with the literature ${ }^{14}$.

Table 1. Characteristics data of the synthesized compounds.

\begin{tabular}{|c|c|c|c|c|c|c|}
\hline \multirow[b]{2}{*}{$\begin{array}{l}\text { Synthesized } \\
\text { compounds }\end{array}$} & \multicolumn{6}{|c|}{ Characteristics } \\
\hline & $\begin{array}{c}\% \\
\text { Yield }\end{array}$ & $\begin{array}{c}\text { Physical } \\
\text { form }\end{array}$ & Color & Solubility & $\begin{array}{l}\text { Melting } \\
\text { point }{ }^{\circ} \mathrm{C}\end{array}$ & $\begin{array}{l}\text { IR spectra, } \\
\mathbf{c m}^{-1}\end{array}$ \\
\hline VTS & 83 & Crystalline & White & $\begin{array}{l}\text { DMSO, } \\
\text { Ethanol. }\end{array}$ & $136-138$ & $\begin{array}{c}\text { 1630sh }(>\mathrm{C}=\mathrm{N}-) \\
1586 \mathrm{~s}\left(\mathrm{C}_{6} \mathrm{H}_{5}\right) \\
1200-1115 \mathrm{w}(\mathrm{C}=\mathrm{S}) \\
\text { 2840s }\left(\mathrm{OCH}_{3}\right) \\
\text { 3530s (phenolic-OH) } \\
\text { 3156s }\left(\mathrm{NH}_{2}\right)\end{array}$ \\
\hline BTS & 76 & Crystalline & White & $\begin{array}{l}\text { DMSO, } \\
\text { Ethanol. }\end{array}$ & $169-170$ & $\begin{array}{c}1658-1619 \mathrm{w}(>\mathrm{C}=\mathrm{N}-) \\
1532 \mathrm{~s}, 3182-3070 \mathrm{w} \\
\left(\mathrm{C}_{6} \mathrm{H}_{5}\right) \\
1164 \mathrm{~s}(>\mathrm{C}=\mathrm{S}) \\
3200 \mathrm{w}\left(\mathrm{NH}_{2}\right)\end{array}$ \\
\hline ATS & 86 & Crystalline & White & $\begin{array}{l}\text { DMSO, } \\
\text { Ethanol. }\end{array}$ & $114-116$ & $\begin{array}{c}1594 \mathrm{~s}(>\mathrm{C}=\mathrm{N}-) \\
1570 \mathrm{~s}\left(\mathrm{C}_{6} \mathrm{H}_{5}\right) \\
1096 \mathrm{~s}, 1060 \mathrm{~s}(>\mathrm{C}=\mathrm{S}) \\
3200 \mathrm{w}\left(\mathrm{NH}_{2}\right)\end{array}$ \\
\hline
\end{tabular}




\section{2. Biological Activities}

The antibacterial activities of these compounds were measured in terms of zone of inhibition are shown in Table 2. The test compounds showed a good sensitivity against a number of pathogenic bacteria. The results were compared with standard drug disc of kanamycin $(30 \mu \mathrm{g} / \mathrm{disc})$.

Table 2. Results of antibacterial activities of the three compounds.

\begin{tabular}{|c|c|c|c|c|c|c|c|c|c|c|c|c|}
\hline \multirow{3}{*}{\multicolumn{2}{|c|}{ 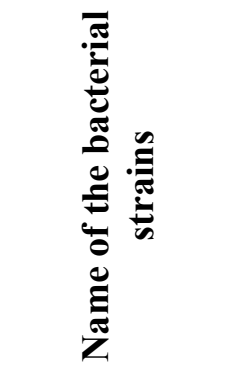 }} & \multicolumn{9}{|c|}{ Diameter of zone of inhibition (mm) } & \multirow{3}{*}{$\begin{array}{l}0 \\
\sum_{2} \\
0 \\
\overrightarrow{0} \\
\frac{1}{0} \\
0\end{array}$} & \multirow{3}{*}{$\begin{array}{c}\text { Standard } \\
\text { (Kanamycin) } \\
30 \mu \mathrm{g} / \mathrm{disc}\end{array}$} \\
\hline & & \multicolumn{3}{|c|}{ (VTS), $\mu \mathrm{g} /$ disc } & \multicolumn{3}{|c|}{ (BTS), $\mu \mathrm{g} / \mathrm{disc}$} & \multicolumn{3}{|c|}{ (ATS), $\mu \mathrm{g} / \mathrm{disc}$} & & \\
\hline & & 100 & 200 & 300 & 30 & 100 & 200 & 30 & 100 & 200 & & \\
\hline \multirow{3}{*}{ 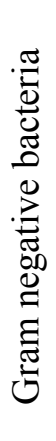 } & S. sonnei & 19 & 22 & 26 & 11 & 20 & 25 & 14 & 20 & 23 & 0 & 29 \\
\hline & E. coli & 18 & 20 & 21 & 10 & 19 & 23 & 12 & 19 & 22 & 0 & 31 \\
\hline & S. shiga & 20 & 21 & 24 & 14 & 23 & 26 & 15 & 23 & 25 & 0 & 27 \\
\hline \multirow{3}{*}{ 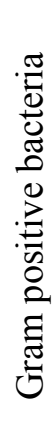 } & $\begin{array}{c}\text { St. } \\
\text { aureus }\end{array}$ & 15 & 18 & 21 & 11 & 21 & 26 & 14 & 21 & 24 & 0 & 29 \\
\hline & B. subtilis & 18 & 19 & 24 & 10 & 22 & 27 & 15 & 22 & 26 & 0 & 30 \\
\hline & S. lutea & 21 & 24 & 27 & 12 & 24 & 26 & 14 & 23 & 25 & 0 & 28 \\
\hline
\end{tabular}

Potency of BTS against all test organisms was quite comparable with that of standard drug kanamycin at dose $30 \mu \mathrm{g} /$ disc. Somewhat better results were obtained when tested with higher doses $(100 \mu \mathrm{g} / \mathrm{disc}$ and $200 \mu \mathrm{g} / \mathrm{disc})$ of the compounds. Other two compounds (VTS and ATS) showed moderate activity. Antibacterial activity of Schiff bases may be written as BTS $>$ ATS $>$ VTS. The solvent DMSO showed no activity against any bacterial strain. MIC values of the test compounds were determined as $\mu \mathrm{g} / \mathrm{mL}$ and are shown in Table 3. 
Table 3. Results of minimum inhibitory concentration of the three compounds.

\begin{tabular}{|c|c|c|c|}
\hline \multirow{2}{*}{ Test organisms } & VTS & BTS & ATS \\
\cline { 2 - 4 } & $\mathrm{MIC} \mu \mathrm{g} / \mathrm{mL}$ & $\mathrm{MIC} \mu \mathrm{g} / \mathrm{mL}$ & $\mathrm{MIC} \mu \mathrm{g} / \mathrm{mL}$ \\
\hline S. sonnei & 32 & 32 & 128 \\
\hline E. coli & 128 & 64 & 128 \\
\hline S. shiga & 128 & 16 & 64 \\
\hline St. aureus & 256 & 32 & 32 \\
\hline B. subtilis & 64 & 128 & 128 \\
\hline S. lutea & 128 & 64 & 64 \\
\hline
\end{tabular}

The brine shrimp lethality bioassay has been chosen to assess the in vitro cytotoxic effect of the test compounds. Median lethal concentration $\left(\mathrm{LC}_{50}\right)$ of brine shrimp lethality was measured from the plots of percentage of mortality versus concentration of the samples (Figure 2). LC $_{50}$ of VTS, BTS and ATS were found to be $30.0,23.5$ and $27.5 \mu \mathrm{g} / \mathrm{mL}$ respectively.

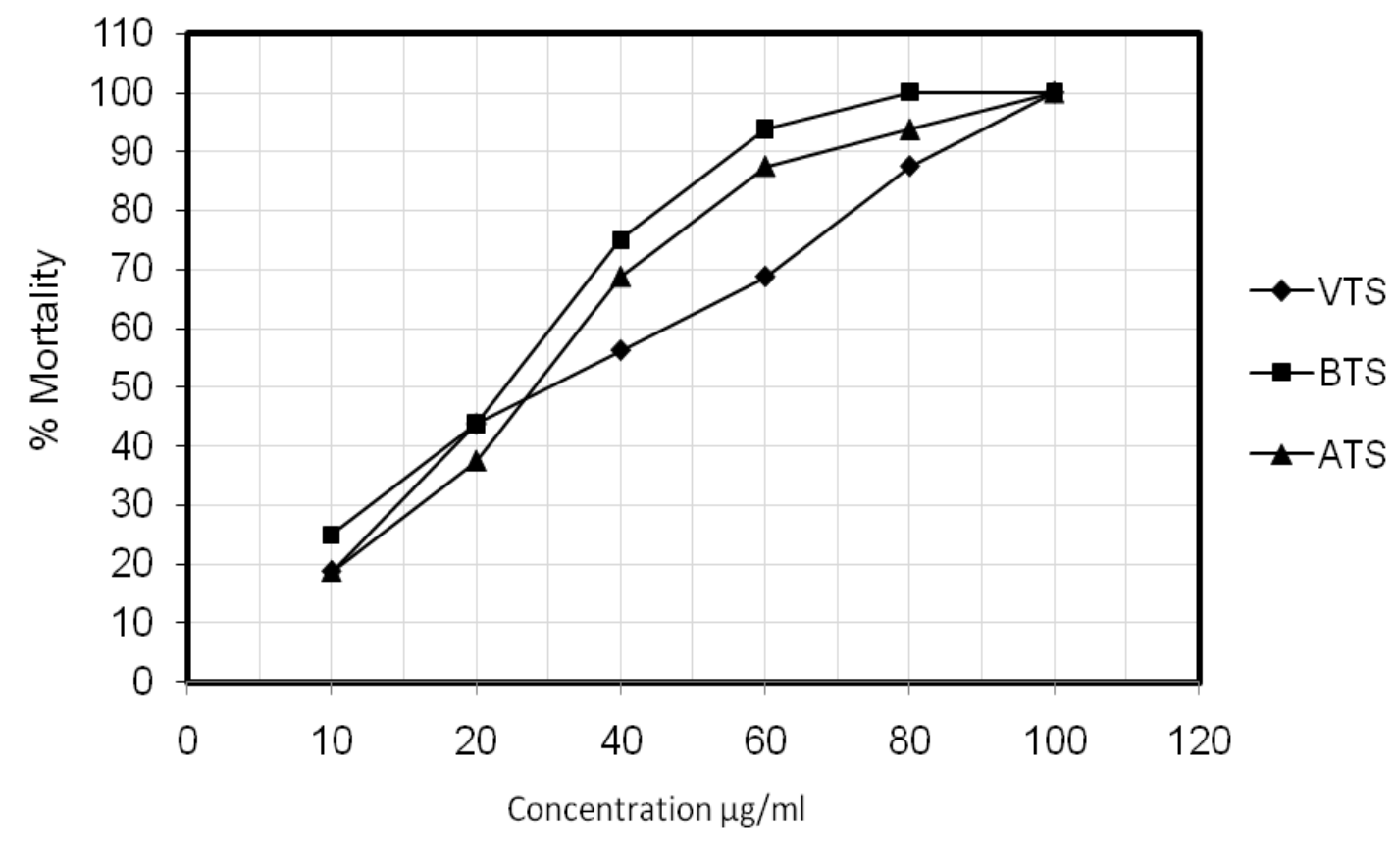

Figure 2. Brine shrimp lethality bioassay of the test compounds. 
From the results discussed above it is clear that the synthesized Schiff bases are biologically active. Among the compounds studied BTS is the most efficient.

\section{CONCLUSIONS}

All the synthesized compounds have been investigated for their antibacterial activities. With our synthesized compounds, it is evident that BTS compound exhibit a significant antibacterial activity and ATS and VTS compounds show a moderate sensitivity even with higher doses. All these compounds were found to possess cytotoxic effect. Therefore, these compounds may be used as new antibacterial drugs after performing further research works with advanced technology.

\section{Acknowledgement}

The authors are thankful to the authorities of the Institute of Biological Science (IBS), University of Rajshahi, Rajshahi-6205, Bangladesh for kindly providing pathogenic microorganisms.

\section{References}

[1] M. M. Ali, M. Jesmin, M. K. Islam, M. A. K Azad, Med. J. Isl. W. Acad. Sci. 21(3) (2013) 47-104.

[2] S. N. Pandeya, G. Nath, E. DeClecq, Euro. J. Pharm. 9(1) 1999) 25-31.

[3] M. R. Islam, A. H. Mirza, Q. M. N. Huda, B. R. Khan, J. Bang. Chem. Soc. 2 (1989) 87-95.

[4] C. Jr. Shipman, S. H. Smith, J. C. Drach, D. L. Klayman, Antiviral Res. 6(4) (1986) 197-22.

[5] Y. Li, Z. S. Yang, H. Zhang, B. J. Caw, F. D. Wang, Bio Org. \& Med. Chem. 11 (2003) 4363-4368.

[6] M. Jesmin, M. M. Ali , M. S. Salahuddin M. R. Habib, J. A Khanam, Mycobiology 36(1) (2008) $70-7$.

[7] M. N. Islam, S. M. S. Shahriar, M. K. Islam, M. Jesmin, M. M. Ali, J. A. Khanam, International Letters of Chemistry, Physics and Astronomy 5 (2013) 12-20.

[8] G. Cerhiaro, A. M. D. Ferreira. J. Braz. Chem. Soc. 17(8) (2006) 1473-1485.

[9] S. N. Pandeya, S. Smitha, M. Jyoti, S. K. Sridhar, Acta. Pharm. (2005) 5527-5546.

[10] V. K. Sharma, S. Srivastava, A. Srivastava, Pol. J. Chem. 80 (2006) 387-396.

[11] M. A. Quraishi, D. Jamal, M. Luqman, Ind. J. Chem. Tech. 9 (2002) 479-483.

[12] B. Glinma, et al., Studies Si Cercetari Stiintifice 12(1) (2011) 33-40.

[13] Comprehensive Organic Chemistry, Barton DH and Ollis WD eds. Oxford Pergamon, Vol. 1979.

[14] M. M. Ali, M. Jesmin, M. K. Islam, F. Khatun, M. A. K Azad, Med. J. Ise. W Acad. Sci. 21(3) (2013) 97-104. 
[15] A. W. Bauer, W. M. M. Kibly, J. C. Sherries, M. Truck, Am. J. Chin. Path. 44 (1966) 493-497.

[16] E. Jawetg, J. L. Melnick, E. A. Adelberg. Review of Medical Microbiology, Lange, Med. Pub. $14^{\text {th }}$ ed. California, 123-24, 1980.

[17] Attaur Rahman, M. I. Chaudhary, W. J. Thomson, Manual of Bioassay Techniques for Natural Product Research. Harwood Acad. Press, Amsterdam, 12-12, 1999. 